\title{
Occurrence of Vibrio and Salmonella species in mussels (Mytilus galloprovincialis) collected along the Moroccan Atlantic coast
}

\author{
Hasna Mannas ${ }^{1}$, Rachida Mimouni ${ }^{1 *}$, Noureddine Chaouqy ${ }^{2}$, Fatima Hamadi ${ }^{1}$ and Jaime Martinez-Urtaza ${ }^{3}$
}

\begin{abstract}
This study reports the occurrence of different Vibrio and Salmonella species in 52 samples of Mytilus galloprovincialis collected from four sites along the Atlantic coast between Agadir and Essaouira (Anza, Cap Ghir, Imssouane and Essaouira). The level of Escherichia coli (E. coli) was also determined to evaluate the degree of microbial pollution in the investigated areas. In this study three methods were used: AFNOR NF EN ISO 6579 V08-013 for Salmonella spp., the provisional method routinely used by several laboratories (Institut Pasteur, Paris,...) for Vibrio cholerae and Vibrio parahaemolyticus in the seafood, and the most probable number method (MPN) using Norm ISO/TS 16649-3 (2005) for E. coli. The most frequently isolated Vibrios were Vibrio alginolyticus ( $90.4 \%$ of samples), followed by $\mathrm{V}$. cholerae non $O 1$ non $O 139$ (15.4\%) and V. parahaemolyticus (7.7\%). Salmonella spp. was found in 15\% of the samples. The number of E. coli ranged between $0.2 / 100 \mathrm{~g}$ and $1.810^{3} / 100 \mathrm{~g}$ of mussel soft tissues. This study indicates the potential sanitary risk associated with the presence of pathogenic bacteria in cultivated mussels in the two populous regions of southern Morocco, where shellfish production and maritime tourism are important to the local economy.
\end{abstract}

Keywords: Salmonella; Vibrio; Escherichia coli; Mytilus galloprovincialis; Agadir; Essaouirra; Morocco; Mussels

\section{Introduction}

Bivalve shellfish are marine invertebrates known to be reliable indicators of pollution in marine environment (Goldberg et al. 1978; Cossa 1989; Ramade 1992). In fact, they present characteristics of bioindicator organisms because they have the capacity to accumulate microorganisms from surrounding waters because of their filterfeeding strategy (Desenclos et al. 1996). Shellfish especially mussels, may be a vehicle for most known pathogen bacteria (Huss 1997). Non-indigenous pathogen bacteria (e.g. Salmonella and Shigella) are introduced into seawater by infected animals and humans, while indigenous bacteria are natural occurring organisms in the marine environment, mainly belonging to the family Vibrionaceae (Potasman et al. 2002). Therefore, these bacteria constitute a potential risk for consumers. Infections were due, either to the consumption of raw or inadequately

\footnotetext{
* Correspondence: r_mimouni@yahoo.fr

${ }^{1}$ Faculty of Sciences, Laboratory of Biotechnology \& Valorisation of Natural Resources, University Ibn Zohr, Agadir, Morocco

Full list of author information is available at the end of the article
}

cooked bivalves, or improperly processed shellfish (FDA 2004). The genus Vibrio is endemic in marine and estuarine ecosystems, and regroups more than 63 species. Since many of them were pathogenic for humans, they had been associated with frequent food-borne infections (Chakraborty et al. 1997). Among these species, 12 might cause gastrointestinal diseases or, in some cases, septicemia. Most of them were caused by Vibrio parahaemolyticus and $V$. vulnificus (Oliver and Kaper 1997).

Several cases of gastroenteritis, due to the consumption of sea products, were listed each year in Morocco (Cohen and Karib 2007) and their etiology was often not known. They might be caused by these Vibrios or any other enteric pathogen or toxin (Cohen and Karib 2007). On the other hand, it had been reported that all the Vibrio collective food poisoning infection in Morocco were due to the consumption of bivalves clandestinely collected (Bouchriti et al. 2001). The prevalence of these Vibrios in Moroccan seafood was already reported by Bouchriti et al. (2001).

\section{实}

C 2014 Mannas et al.; licensee Springer. This is an Open Access article distributed under the terms of the Creative Commons Attribution License (http://creativecommons.org/licenses/by/4.0), which permits unrestricted use, distribution, and reproduction in any medium, provided the original work is properly credited. 
In Morocco, few studies (Bouchriti et al. 2001; Cohen and Karib 2007; Setti et al. 2009) have been done on the occurrence of the pathogenic bacteria in the seafood in order to better estimate the prevalence of these pathogens in the marine environment. Such studies are necessary to carry out the analysis of risk associated with these pathogens to reduce the manifestation of collective food poisoning infection. The first aim of this study was to investigate the occurrence of Vibrio and Salmonella in Mytilus galloprovincialis along the Moroccan Atlantic coast between Agadir and Essaouirra. The second aim was to determine the existence of any correlation between the occurrence of Vibrio spp. and Escherichia coli (indicator bacteria).

\section{Materials and methods \\ Study area}

This area is located along the West Atlantic coast of Morocco which extends from Anza to Essaouirra and has a length of approximately $150 \mathrm{~km}$ (Figure 1). This coast is characterized by many natural beds of mussels (M. galloprovincialis). This work was realized in two bays (Agadir and Essaouirra). Agadir is located in West Central Morocco between approximately $9^{\circ} 13^{\prime} 10$ "and $9^{\circ} 53^{\prime} 30^{\prime \prime}$ degrees West longitude and $30^{\circ} 56^{\prime} 00^{\prime \prime}$ and $30^{\circ}$ 20 '50" north latitude.

Agadir is characterized by a semiarid climate with a cool and a warm season. The average temperature between 2000 and 2012 is $26^{\circ} \mathrm{C}\left(21^{\circ} \mathrm{C}-31^{\circ} \mathrm{C}\right)$. The temperature can reach over $40^{\circ} \mathrm{C}$ under the influence of high saharien winds. The average of rainfall between 2000 and 2012 is $243 \mathrm{~mm} /$ year. The rainy season mainly occurs in the fall and in the first weeks of winter according to data obtained from the Regional Office of the Development of Agricultural Souss Massa. Coastal waters of Agadir bay are influenced by two types of currents: the Canary current, moving to the southwest at a speed of 0.5 knots $(0.5$ nautical mile/h). The second is the Upwelling characterized by deep water rising to the website surface resulting in high concentrations of nutrients especially in summer (Mimouni et al. 2003; Mimouni, 2004; Orbi, 1991).

Essaouirra is a city in the western Moroccan. The climate of Essaouirra is arid with a dry period of six to seven months. The average temperature of Essaouirra is $16.7^{\circ} \mathrm{C}$, with a relatively small difference between the average temperatures of the warmest and the coolest month. Essaouirra is characterized by a rainy season from October to May and an average dry season (June-September). The average rainfall is $280 \mathrm{~mm} /$ year. It's also characterized by the influence of the Upwelling of cold water along the coast by the predominance of maritime origin strong winds throughout the year. Strong winds are constant at Essaouira.

Four sites were selected for this study: i) Anza ( $30^{\circ} 26^{\prime} \mathrm{N}$, $9^{\circ} 38^{\prime} \mathrm{W}$ ) which receives discharges of domestic sewage and industrial untreated waters; ii) Cap Ghir $\left(30^{\circ} 0^{\prime} \mathrm{N}, 9^{\circ}\right.$ $\left.53^{\prime} \mathrm{W}\right)$ characterized by the presence of natural deposit and a major tourism activity. We considered this site as site reference; iii) the Imsouane bay $\left(30^{\circ} 50^{\prime} .46^{\prime \prime} \mathrm{N}, 9^{\circ}\right.$ $\left.46^{\prime} .44^{\prime \prime} \mathrm{W}\right)$ is located at $100 \mathrm{~km}$ from Agadir; this site corresponding to the mouth of the Tablast river, is known

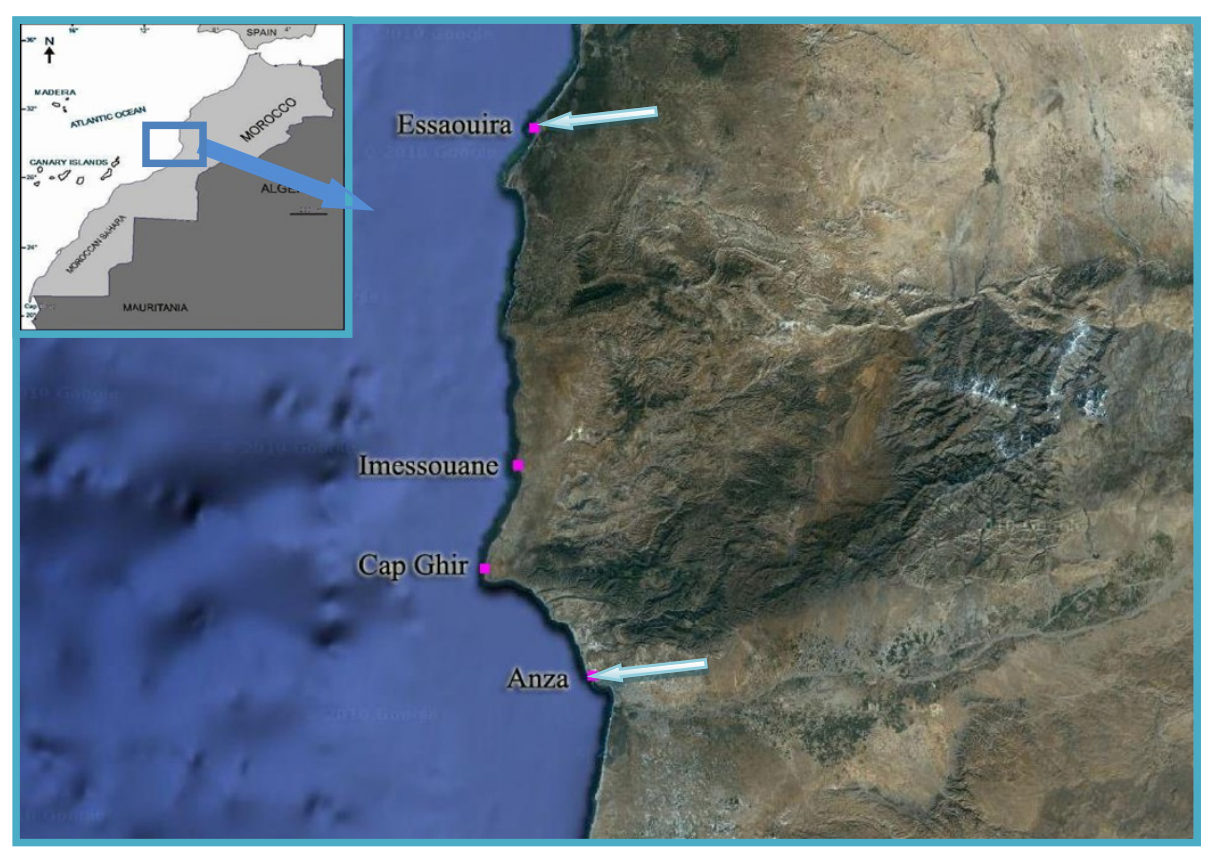

Figure 1 The four mussel beds investigated along the Atlantic coast from April 2010 until April 2011 (Arrows indicate the location of wastewater discharges). 
to be a center for speedboaters, canoeists and fishing; iv) Essaouirra $\left(31^{\circ} 54^{\prime} \mathrm{N}, 9^{\circ} 76^{\prime} \mathrm{W}\right)$ subjected to a great environmental pollution (discharge of sewages and garbage).

\section{Seawater physicochemical parameters}

Temperature, salinity and $\mathrm{pH}$ were measured along the sampling period (April 2010-April 2011). The temperature of seawater was measured using a laboratory thermometer. The $\mathrm{pH}$ was measured by a $\mathrm{pH}$-meter (WTW $\mathrm{pH}$ 522), and values of salinity were detected using a salinometer (W.T.W.LF18, Measuring Cells Tetracon 325).

\section{Sample collection and preparation}

Every month, 52 mussel samples were collected from the four sampling sites between April 2010 and April 2011 to detect the presence of Vibrios and Salmonellae. Each sample consisted of 30 specimens of $M$. galloprovincialis. These bivalves were placed into sterile bags and transported to the laboratory under a temperature of $4^{\circ} \mathrm{C}$. All samples were examined within two hours following their collection. At their arrival in the laboratory, the mussels were scrubbed under running tap water to remove shell debris and attached algae. They were then dried and aseptically opened using a sterilized scalpel.

\section{Isolation and biochemical identification of Vibrios}

Vibrio isolation was performed with a provisional method routinely used by several laboratories: National Reference Center for Vibrios and Cholera, Institut Pasteur, Paris, France; Laboratory of Studies and Research in Environment and Health, National School of Public Health, Rennes, France; Laboratory for Studies and Research on Fishery Products, AFSSA-Site of Boulogne, Boulognesur-Mer, France.

A 1:9 dilution was first prepared with $25 \mathrm{~g}$ of soft tissue and intervalvular liquid in $225 \mathrm{~mL}$ of Alkaline peptone water (APW) (Yeast extract $3 \mathrm{~g}$, peptone $10 \mathrm{~g}$, sodium chloride $20 \mathrm{~g} / \mathrm{L}$ and distilled water $1 \mathrm{~L}$ at $\mathrm{pH}$ 8.6). The mix was homogenized and incubated at $42{ }^{\circ} \mathrm{C}$ for $18 \mathrm{~h}$ for its enrichment and cell growth. An aliquot was innocullated in Thiosulfate citrate bile sacharose agar (TCBS) (Scharlau Chimie, Spain) and CHROMagar Vibrio chromogenic medium (Oxoid, Wesel, Germany). These media were then incubated at $37^{\circ} \mathrm{C}$ for $18-24 \mathrm{~h}$. A minimum of five typical colonies were picked and cultured on Marine agar to determine their purity (ZoBell 1941). The pure cultures of isolated colonies were subjected to a battery of tests for morphological and biochemical identification. Strains were identified by Gram staining and cytochrome oxidase activity. Only Gram-negative, oxidase-positive colonies were selected for biochemical tests, following classical procedures. The API 20E system, and culture in $0 \%, 3 \%, 6 \%, 8 \%$ and $10 \% \mathrm{NaCl}$ peptone water were used to identify the Vibrio species (Hara-Kudo et al. 2001). Serotyping strains of $V$. cholerae consisted of a slide agglutination test with a 24 hour culture on Marine Agar (MA), a test in physiological saline was performed to verify that the strains were not autoagglutinables. The Suspected colonies resembling $V$. cholerae were tested by slide agglutination with polyvalent anti-O1 and anti-O139 sera.

\section{Isolation and biochemical identification of Salmonella}

These bacteria were isolated according to the norm ISO 6579 (2002). Briefly, $225 \mathrm{~mL}$ of Buffered peptone water was added to $25 \mathrm{~g}$ of homogenized mussel soft tissues and incubated at $37^{\circ} \mathrm{C}$ for $20 \mathrm{~h}$. After this preenrichment step, $0.1 \mathrm{~mL}$ of the solution was transferred in $10 \mathrm{~mL}$ of the Rappaport-vassiliadis Broth (Scharlau Chemie, Spain) and the mix was incubated at $41,5^{\circ} \mathrm{C}$ for $24 \mathrm{~h}$. Other $1 \mathrm{~mL}$ were added to $10 \mathrm{~mL}$ of the Muller-Kauffman au Tetrathionate-Novobiocine (MKTTn) (Scharlau Chemie, Spain) and were incubated at $37^{\circ} \mathrm{C}$ for $24 \mathrm{~h}$. The enriched suspensions were then plated on Rambach Agar (Merck) and on Xylose Lysin Desoxycholate Agar (Scharlau Chemie, Spain), and were incubated at $37^{\circ} \mathrm{C}$ for $24 \mathrm{~h}$. Suspect colonies were purified with Tryptone Sulfite Neomycin agar (TSN) (Scharlau Chemie, Spain), and confirmed biochemically with the API $20 \mathrm{E}$ system (bioMérieux, Marcy-l'Étoile, France).

\section{Enumeration of Escherichia coli}

The most probable number (MPN) of E. coli in samples was determined using the multiple tube method with the 5-tubes-3-dilutions test according to the norm ISO/ TS 16649-3 (2005). Seventy-five grams of flesh and intervalvar liquid (FIL) were diluted 1:3 with the Tryptone salt water (biokar Diagnostics) and the mix was homogenized using a food homogenizer (Stomacher) for 2 min to obtain a stock suspension. Thirty $\mathrm{mL}$ of this mix were added to $70 \mathrm{~mL}$ of Tryptone salt water (biokar Diagnostics) and were homogenized to reach a 1:10 dilution. Ten $\mathrm{mL}$ of this homogenate were inoculated into five tubes of double concentrate of Minerals Modified Glutamate Broth (MMGB). Five tubes of normal concentration MMGB were inoculated with $1 \mathrm{~mL}$ of the 1:10 homogenate, while the other five tubes were inoculated with $1 \mathrm{~mL}$ of a 1:100 dilution per tube. After homogenizing, all the tubes were incubated at $37^{\circ} \mathrm{C}$ for $24 \mathrm{~h}$. Escherichia coli confirmation was performed by culturing $1 \mathrm{uL}$ of positive tubes (tubes showing acid production) on the Tryptone Bile X-Glucuronide agar (TBX) (Oxoid, Wesel, Germany), and by incubating them at $44^{\circ} \mathrm{C}$ for $24 \mathrm{~h}$. The growth of blue colonies indicated the presence of $E$. coli. The number of $E$. coli per $100 \mathrm{~g}$ was determined using MPN tables (ISO/TS 16649-3 (2005)) according to the number of positive results in the three dilutions. 


\section{Statistical analysis}

After all parameters were considered; to evaluate if there are any correlation between these parameters, Principle Components Analysis was conducted by Statistica software V6.

\section{Results}

Isolation and biochemical identification of Vibrios

Among the 52 samples examined, Vibrio spp. was found in the four sites, with percentages ranging from $7.7 \%$ to $100 \%$ (Table 1). The use of two agar media (TCBS and the CHROMagar Vibrio chromogenic medium) in the present study to isolate the Vibrio spp. influence the detection of higher number of positives samples. Our findings suggest that the CHROMagar Vibrio medium was more efficient and accurate for identifying Vibrio spp. in mussels than the conventional TCBS agar. Otherwise serological analysis strains identify $V$. cholerae shows no agglutination with the serum anti-O1 and antiO139 serum.

$V$. alginolyticus was detected in $90.4 \%$ of the samples collected at the four sites during all the period of our study (Table 1). V. cholera non $\mathrm{O} 1$ non $\mathrm{O} 139$ was detected in $15.4 \%$ of the samples (Table 1). This bacterium is very abundant in August, November and February, in the Essaouirra site (Figure 2D). Also in Anza site this pathogen germ was isolated between August and December (Figure 2A). The prevalence of this bacterium was lower, it was found only in April and July in Cap Ghir (Figure 2B) and Imssouane respectively (Figure 2C).

For $V$. parahaemolyticus $15.4 \%$ and $7.7 \%$ of samples were contaminated in Anza and Essaouirra respectively (Table 1). Generally, it was found in July in the Essaouirra site (Figure 2D) and February in Imssouane site (Figure 2C). For the other sites, this pathogen germ was almost absent in Cap Ghir (Figure 2B), but at Anza site this bacteria was observed at March and April (Figure 2A).

$V$. alginolyticus, $V$. parahaemolyticus and $V$. cholerae non $\mathrm{O} 1$ non $\mathrm{O} 139$ represented the found species in the four sites studied. $V$. alginolyticus was the most abundant species recovered from all the samples. The variation of number of Vibrio isolate with rainfall was presented in
Figure 3. We observed that the number of $V$. cholerae non $\mathrm{O} 1$ non $\mathrm{O} 139$ and $V$. parahaemolyticus isolate decreased with rainfall in all sites and particularly in Anza (Figure 3A) and Essaouira (Figure 3D).

\section{Occurrence of Salmonella}

In the present study, Salmonella spp. was recovered from $15.4 \%$ of mussel samples (Table 1). The eight positive samples were collected from three sites (Anza, Imssouane and Essaouira) (Figure 4). The highest prevalence of Salmonella was noted in the samples collected from Anza (38.5\%) (Table 1). Salmonella was predominantly detected during the rainy and cool season between September and January (Figure 4A). In Essaouira site Salmonella was found in $15.4 \%$ of samples (Table 1 ), this bacterium is abundant in November and February (Figure 4D). The lower prevalence of Salmonella was registered in Imssouane site where only one positive sample was detected in February (Figure 4C). The relation between the number of Salmonella spp and rainfall was presented in Figure 5. No relation was observed between the presence of Salmonella spp. and rainy periods.

\section{Escherichia coli enumeration}

The number of $E$ coli detected in Anza ranged from $1.410^{2} / 100 \mathrm{~g}$ to $1.810^{3} / 100 \mathrm{~g}$ (Figure $6 \mathrm{~A}$ ). The highest evels of $E$. coli were detected during the dry season. In Essaouirra, the lowest (2.2/100 g) and highest $\left(1.610^{2} / 100 \mathrm{~g}\right)$ $E$. coli counts were found in December and November respectively (Figure 6D). The maximum level of E. coli was observed in December when rainfall was present few days before sampling at Cap Ghir (Figure 6B) whereas it was obtained in April at Imssouane site (Figure 6C).

Statistical analysis was performed by the principal component analysis (PCA) which shows that there is no correlation between the presence of pathogenic Vibrios and Salmonella spp. in mussels and the presence of the E. coli contamination. The results of $E$. coli concentration variation with rainfall are illustrated in Figure 7 . These results show that the concentration of E. coli was mostly limited to the rainy period in all sites.

Table 1 Prevalence of positive samples of mussels for Vibrio spp. and Salmonella spp. for each sites studied between April 2011 and April 2012

\begin{tabular}{llll}
\hline Sites & V. alginolyticus & V. cholerae & V. parahaemolyticus \\
\hline Anza & $76.9(10 / 13)^{*}$ & $23.1(3 / 13)$ & $15.4(2 / 13)$ \\
Cap Ghir & $92.3(12 / 13)$ & $7.7(1 / 13)$ & $0(0 / 13)$ \\
Imssouane & $92.3(12 / 13)$ & $7.7(1 / 13)$ & $7.7(1 / 13)$ \\
Essaouira & $100(13 / 13)$ & $23.1(3 / 13)$ & $7.7(1 / 13)$ \\
All sites & $90.4(47 / 52)$ & $15.4(8 / 52)$ & $7.7(4 / 52)$ \\
\hline
\end{tabular}

* $(a / b):(a=$ Number of positive samples $/ b=$ Total number of samples analyzed for each site). 

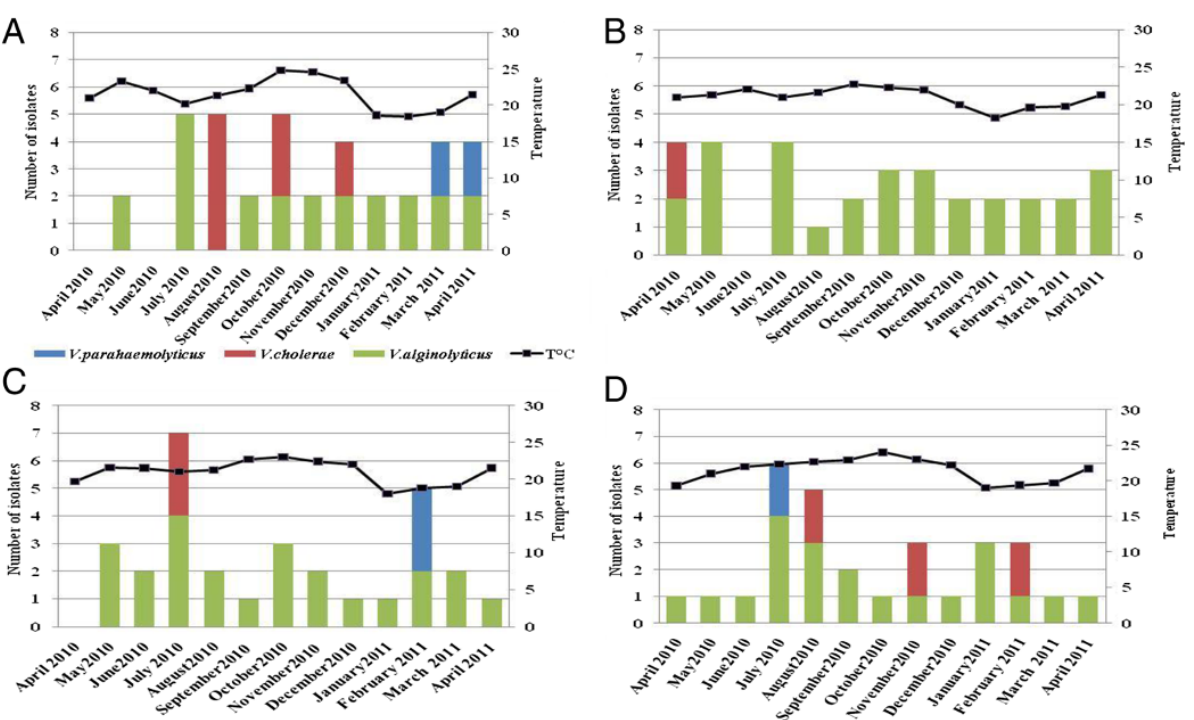

Figure 2 Monthly variations of seawater temperature and number of Vibrio isolates containing in mussels in the four sites: Anza (A), Cap Ghir (B), Imssouane (C) and Essaouira (D).

\section{Principal component analysis}

The principal component analysis (PCA) was performed on the physicochemical of seawater (Table 2) and bacteriological variable of mussels collected in the four sites (Table 3). The projection of the variables on the two axes of the PCA indicates that the two axes of the PCA represented $62.97 \%$ of the total inertia. Circle correlation of variables showed that $V$. parahaemolyticus and $\mathrm{pH}$ are positively correlated with respect to the axis 1 . By one against the temperature correlated negatively with respect to the axis 1 . Thus, the variables E. coli and Salmonella spp are negatively correlated with axis 2 against salinity correlates positively with axis 2 . In addition, the two variables salinity and $V$. parahaemolyticus systematically oppose against axis 2. The number of isolates of $V$. parahaemolyticus is very important in the Anza site and has low salinity values in reports to site Cap Ghir (Figure 8A). The two axes of the PCA factorial account $62.97 \%$ of the total inertia (Figure $8 \mathrm{~B}$ ). Therefore two different groups are distinguished. A first group gathering sites 2 and 3 corresponding to the Cap Ghir and Imssouane, the second gathering sites 1 and 4 corresponding to Anza and

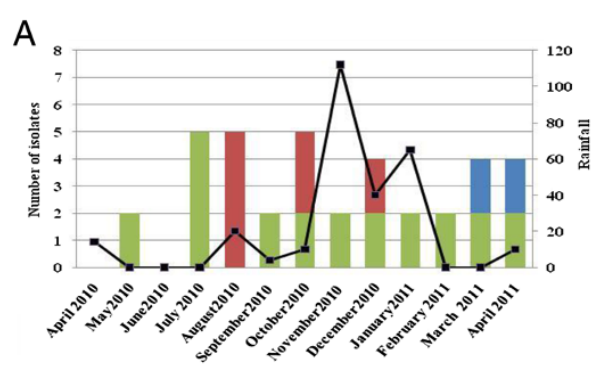

C

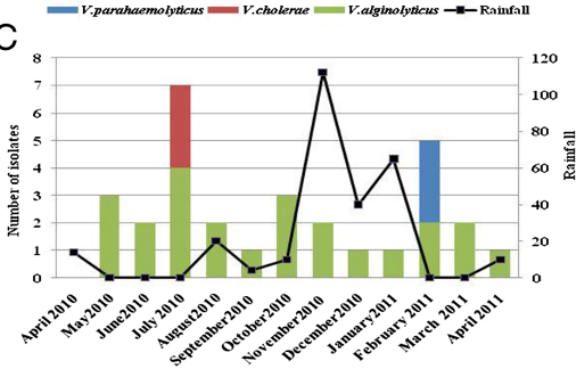

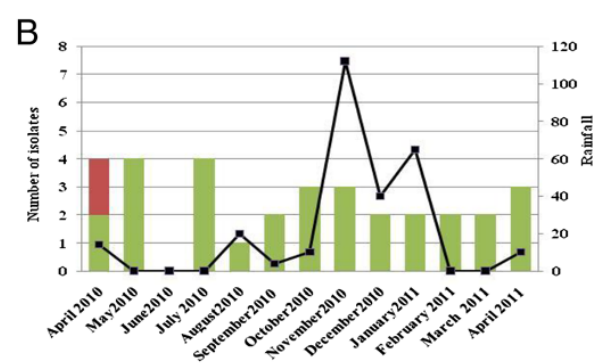

D

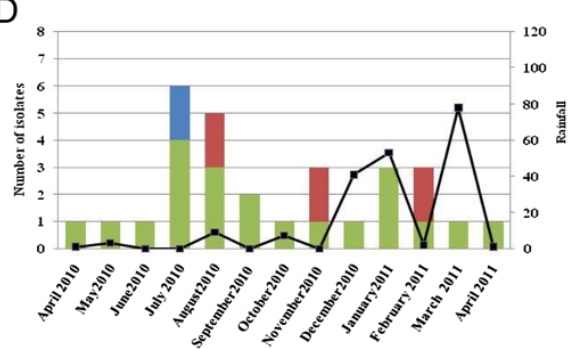

Figure 3 Relationship between number of Vibrio isolates and rainfall in the sites studied Anza (A), Cap Ghir (B), Imssouane (C) and Essaouira (D). 


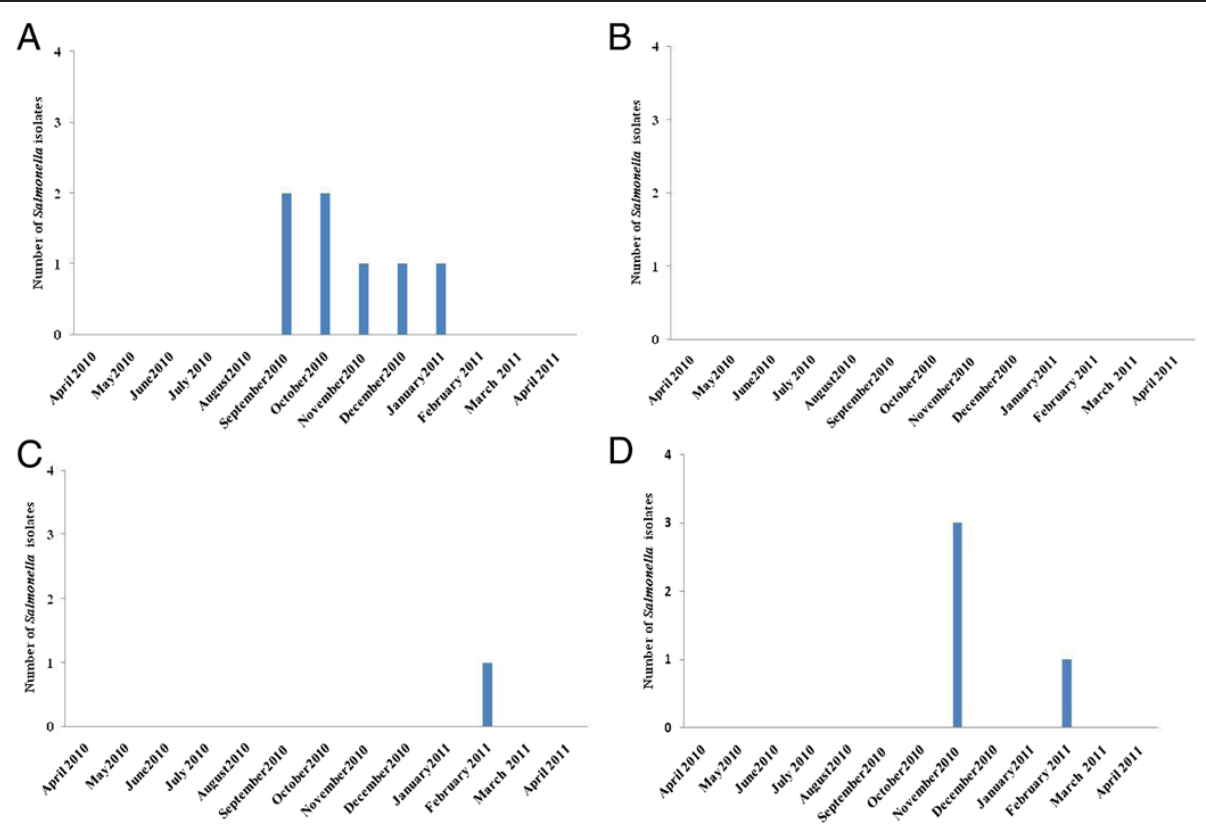

Figure 4 Number of Salmonella spp. isolates containing in mussels in the four sites: Anza (A), Cap Ghir (B), Imssouane (C) and Essaouira (D).

Essaouirra sites. The comparison of the two PCA (Circle correlation of variables and factorial PCA) shows that the first group has a strong correlation with salinity. This indicates salinity is very important in the waters of Cap Ghir and Imssouane sites. The second group is divided into three subgroups. A first subgroup represented by the site of Essaouira and the Anza site with three seasons. This subgroup is strongly correlated with Salmonella spp., it shows that the mussels taken from these two sites present a high concentration of these bacteria. The second subgroup is represented solely by the Anza site summer season and strictly correlates with E. coli. Mussels collected on this site have high rates of $E$. coli during the summer. The third group presents Essaouirra during the winter season it is

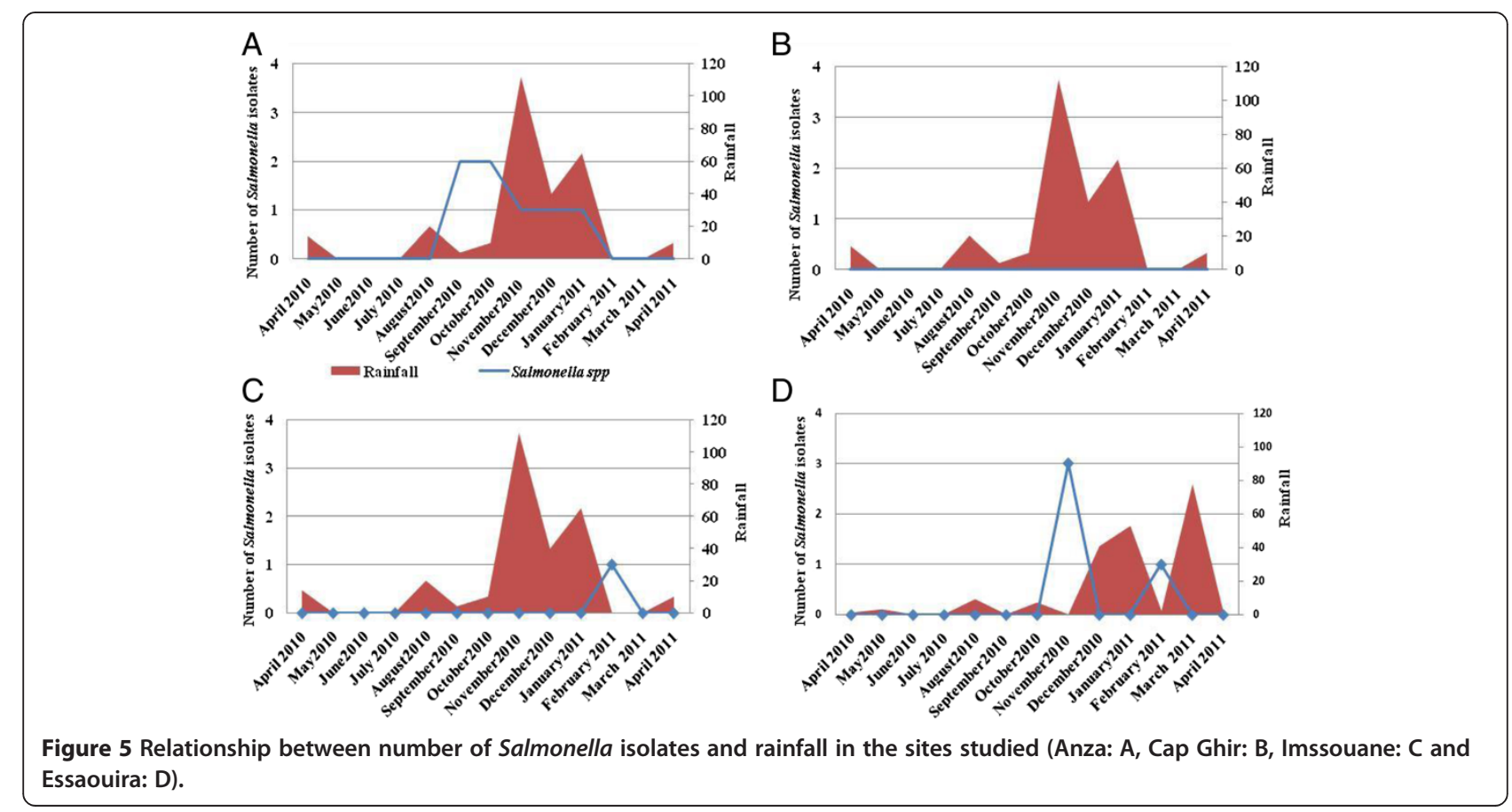




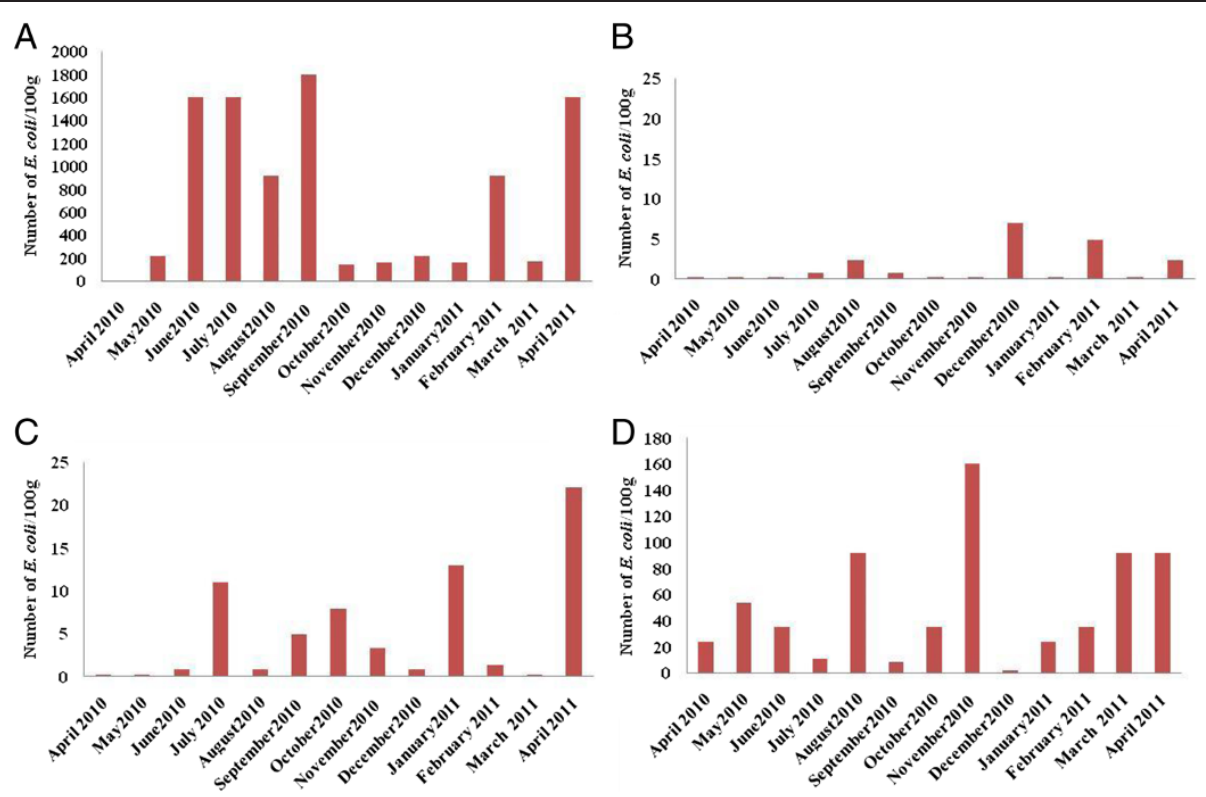

Figure 6 Number of E. coli/100 g containing in mussels in the sites studies: Anza (A), Cap Ghir (B), Imssouane (C) and Essaouira (D).

strongly correlated with $V$. parahaemolyticus indicates that this organism is very important in mussels collected during this period.

The examination of correlation coefficients between the variables (Table 3) shows that the $\mathrm{pH}$ has a significant and negative correlation with $E$. coli $(\mathrm{r}=-0.71)$.

\section{Discussion}

The major objective of this study was to determine the prevalence of potentially pathogenic Vibrio spp., Salmonella spp. and E. coli in mussel (M. galloprovincialis), collected from Agadir and Essaouira coastal areas that vary in water temperature and salinity. Vibrio spp. was
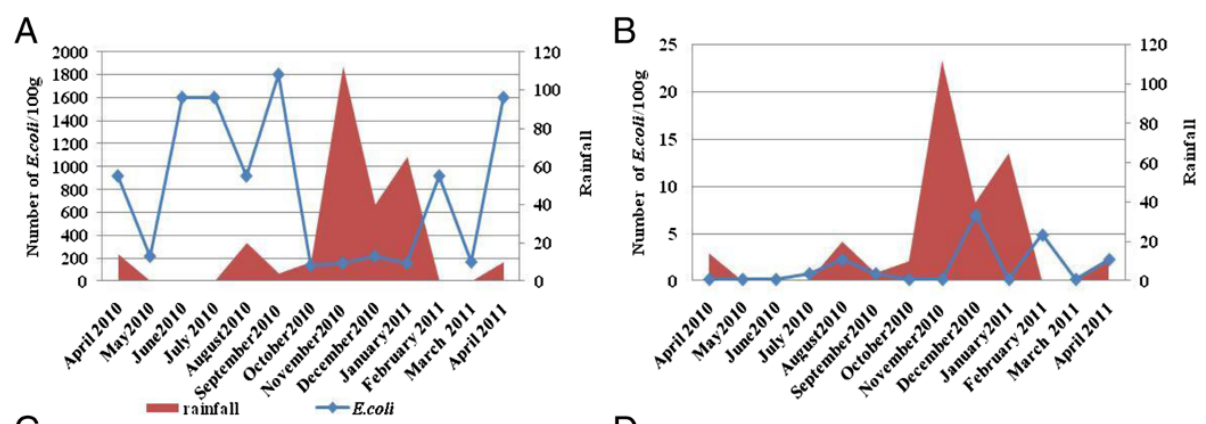

C

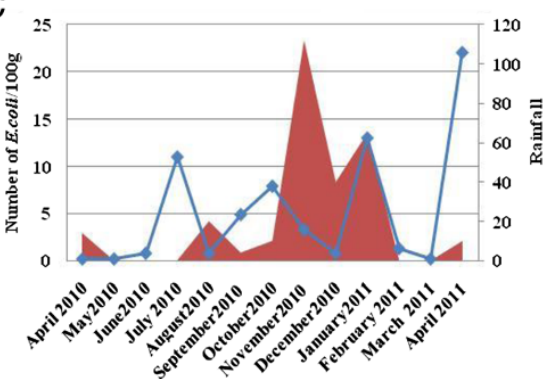

D

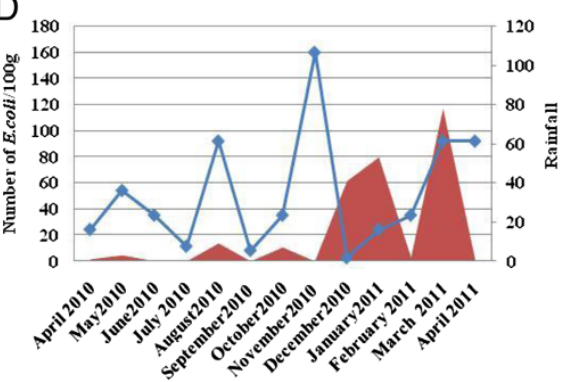

Figure 7 Relationship between number of E. coli isolates and rainfall in the sites studied: Anza (A), Cap Ghir (B), Imssouane (C) and Essaouira (D). 
Table 2 Correlation matrix obtained from the principal component analysis of physicochemical and bacteriological parameters of mussels collected from the study sites

\begin{tabular}{lllllll}
\hline Parameter & $\mathbf{T}^{\circ} \mathbf{C}$ & $\mathbf{p H}$ & Salinity & V. $\boldsymbol{p}$. & S. spp. & E. coli \\
\hline $\mathrm{T}^{\circ} \mathrm{C}$ & 1 & -0.062478 & 0.320826 & 0.255041 & 0.363347 & 0.036097 \\
$\mathrm{pH}$ & -0.062478 & 1 & -0.099246 & 0.181816 & -0.154248 & -0.710888 \\
Salinity & 0.320826 & -0.099246 & 1 & -0.508414 & -0.300831 & -0.196118 \\
V. p. & 0.255041 & 0.181816 & -0.508414 & 1 & 0.258185 & 0.054976 \\
S. spp. & 0.363347 & -0.154248 & -0.300831 & 0.258185 & 1 & 0.233055 \\
E. coli & 0.036097 & -0.710888 & -0.196118 & 0.054976 & 0.233055 & 1 \\
\hline
\end{tabular}

V. p.: Vibrio paraheamolyticus, S. spp.: Salmonella spp., E. coli: Escherichia coli, $T^{\circ}$ : Temperature.

found in all the sites, with percentages ranging from $7.7 \%$ to $100 \%$.

Compared to the other reports which investigated the mussels (M. edulis and M. galloprovincialis), the percentage of Vibrio-positive samples in the present study was higher than the occurrence found in previous studies carried out in Germany (Wadden Sea: 74.4\%), Ionian (Mar Piccolo of Taranto Sea: 60\%) and Italy (Adriatic Sea: 48.4\%) (Lhafi and Kuhne 2007; Cavallo and Stabili 2002; Ripabelli et al. 1999). The difference obtained between our results and these reports may be associated with the existence of different climate conditions in the different areas. Additionally, the use of two agar media (TCBS and the CHROMagar Vibrio chromogenic medium) in the present study to isolate the Vibrio spp., may also influence the detection of higher number of positives samples with respect to previous studies (e.g., Lhafi and Kuhne (2007) and Ripabelli et al. (1999)) which used TCBS medium only. CHROMagar Vibrio medium contains substrates for beta-galactosidase. It was specifically developed to differentiate $V$. parahaemolyticus from $V$. vulnificus, $V$. cholerae non $\mathrm{O} 1$ non $\mathrm{O} 139$ and other Vibrios directly at the isolation step on colony color by using a chromogenic substrate (instead of sugar fermentation in traditional growth media such as TCBS). On the CHROMagar Vibrio medium, $V$. parahaemolyticus colonies were purple. Those of $V$. vulnificus and $V$. cholerae appeared

Table 3 Annual averages of physicochemical parameters

\begin{tabular}{llll}
\hline Sites & $\begin{array}{l}\text { Temperature* } \\
\text { (Min-Max) }\end{array}$ & $\begin{array}{l}\mathbf{p H}^{*} \\
\text { (Min-Max) }\end{array}$ & $\begin{array}{l}\text { Salinity* } \\
\text { (Min-Max) }\end{array}$ \\
\hline Anza & 21.6 & 7.5 & 35.2 \\
& $18.6-24,8$ & $6.7-8$ & $31.6-36.1$ \\
Cap Ghir & 21.0 & 7.8 & 36.4 \\
& $18.2-22.7$ & $7.6-8.1$ & $35.9-37.1$ \\
Imssouane & 21.0 & 7.6 & 36.4 \\
& $18-23$ & $7.4-7.9$ & $37.2-34.3$ \\
Essaouirra & 21.5 & 7.7 & 34.8 \\
& $19-24$ & $7.3-7.9$ & $30-36$ \\
\hline
\end{tabular}

*The value is the average of thirteen values (April 2010-April 2011). blue, while $V$. alginolyticus colonies were colorless. Our findings suggest that the CHROMagar Vibrio medium was more efficient and accurate for identifying Vibrio spp. in mussels than the conventional TCBS agar. This result agreed with the reports of Di Pinto et al. (2011), Croci et al. (2007) and Blanco-Abad et al. (2009).

$V$. alginolyticus, $V$. parahaemolyticus and $V$. cholera non $\mathrm{O} 1$ non $\mathrm{O} 139$ represented the found species in the four sites studied. $V$. alginolyticus was the most abundant species recovered from all the samples. In fact, seawater is the normal habitat for $V$. alginolyticus and was isolated from seawater and seafood in many parts of the world. The study of Matte et al. (1994) reported that the $V$. alginolyticus was the most common Vibrio species found in the Perna perna from the Atlantic coastal of Brazil, furthermore Ripabelli et al. (1999) found similar results for the M. galloprovincialis harvested from Adriatic sea in Italy. These results were in agreement with the reports by Cavallo et al. in Mar Piccolo of Taranto (Ionian Sea) (2002), Hervio-Heath et al. (2002) in coastal areas of France, and Covazzi Harriague et al. (2008) in northern Adriatic Sea (Italy) who studied the $M$. galloprovincialis, mussels (M. edulis and M. galloprovincialis), and sedimentary crustaceans (copepods and anphipods) respectively.

The number of isolates of Vibrio especially $V$. cholerae non $\mathrm{O} 1$ non $\mathrm{O} 139$ and $V$. parahaemolyticus in the study site particularly in Anza and Essaouira decreased with rainfall. The result of this study is in contrast to the results of Yamazaki and Esiobu (2012) who found a correlation between the rainfall dates and the incidence of pathogenic Vibrio species.

Except Cap Ghir site, Salmonella spp. was found in all sites. The highest prevalence (38.5\%) of Salmonella was noted in the samples collected from Anza. Our results are similar to several reports (Brands et al. 2005; Setti et al. 2009; Bakr et al. 2011). Brands et al. (2005) detected the presence of these bacteria in oysters $(7.4 \%)$ from different coasts of the United States. Setti et al. (2009) reported the prevalence of Salmonella in 10\% of 801 samples of mussels collected from Agadir coast. 


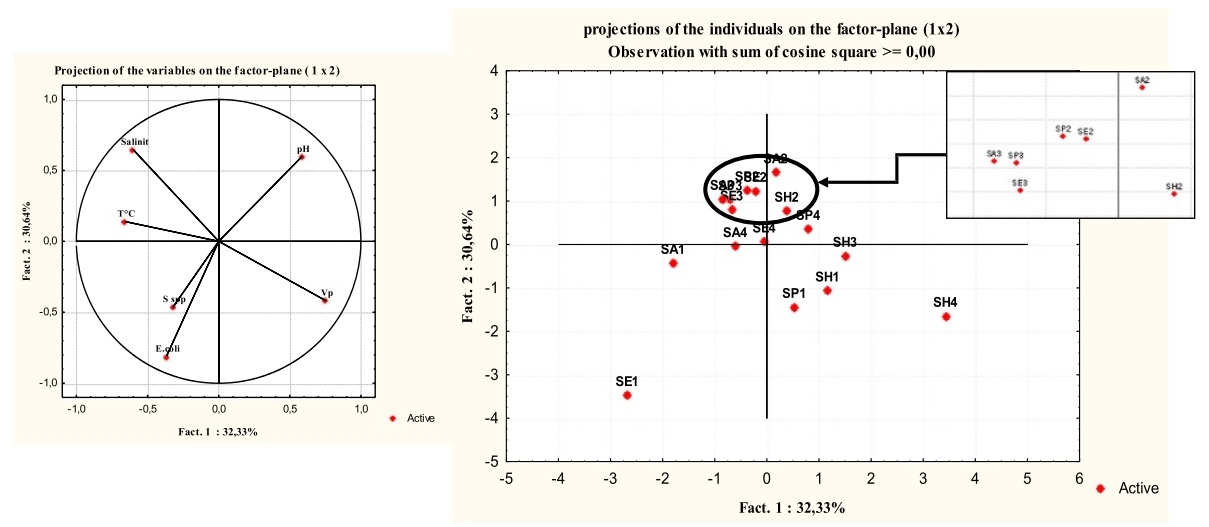

Figure 8 Principal Component Analysis concerning the parameters physicochemical and bacteriological at the four sites studied. Spp: Salmonella spp; Vp: Vibrio parahaemolyticus; $\mathbf{T}^{\circ}$ : Temperature; E. coli: Escherichia coli; SP1: Anza spring; SE1: Anza summer; SA1: Anza autumn; SH1: Anza winter; SP2: Cap Ghir spring; SE2: Cap Ghir summer; SA2: : Cap Ghir autumn; SH2: Cap Ghir winter ; SP3: Imssouane spring; SE3: Imssouane summer; SA3: Imssouane autumn; SH3: Imssouane winter; SP4: Essaouira spring; SE4 : Essaouira summer; SA4: Essaouira autumn.

Bakr et al. (2011) found this bacterium in $8.0 \%$ of their samples (Alexandria, Egypt). In a recent study by Boutaib et al. (2011) carried out in Morocco (Rabat) on faecal contamination using 104 samples of Callista chione and Acanthocardia tuberculatum, indicated that the presence of Salmonella was detected in 7 samples of A. tuberculatum and two of $\mathrm{C}$. chione.

Our results show that the presence of salmonella was reduced in rainy periods. These findings were in agreement with Simental and Martinez-Urtaza (2008) who found that the presence of Salmonella spp. in coastal areas was mostly confined to rainy periods. On the other hand our results were in contrast with reports of Martinez-Urtaza et al. 2008 and Setti et al. 2009, who reported that the incidence of Salmonella spp. was associated with high rainfall.

E. coli was detected in Anza with values ranging from $1.410^{2} / 100 \mathrm{~g}$ and $1.810^{3} / 100 \mathrm{~g}$. The highest levels of $E$. coli were detected during the dry season. In Essaouirra, the lowest and highest E. coli counts were noted in December and November respectively. The maximum load of $E$. coli was observed in December when rainfall was present few days before sampling. Higher levels of $E$. coli were detected throughout almost all the months of the year at Anza and Essaouirra. Indeed, these sites received continuous discharges coming from domestic and industrial wastewater without any prior treatment (Mimouni 2004, 2002). The variation of the concentration of $E$. coli with rainfall shows that the number of $E$. coli was mostly limited to the rainy period in all sites. These findings were in accordance with the work of Kleinheinz et al. (2009). In this work the authors found that the concentration of $E$. coli decreases with rainfall.

Statistical analysis (PCA) shows that there is no correlation between the presence of pathogenic Vibrios and Salmonella spp. in mussels and the presence of the $E$. coli contamination. This is consistent with the findings of other authors (Matté et al. 1994; Normanno et al. 2006). In the study of Boutaib et al. 2011, the faecal contamination (counts of $E$. coli) was high through the year and above of the threshold $230 \mathrm{E}$. coli/100 g in both bivalves harvested from Fnideq location (Morocco).

he principal components analysis (PCA) was performed on the physicochemical of seawater and bacteriological variable of mussels collected in all the sites investigated. The result indicates that $V$. parahaemolyticus and $\mathrm{pH}$ are positively correlated with respect to the axis 1 . E. coli and Salmonella spp. are negatively correlated with axis 2 against salinity correlates positively with axis 2 . In addition, the two variables salinity and $V$. parahaemolyticus systematically oppose against axis 2. The PCA analysis distinguishes two different groups. A first group gathering sites 2 and 3 corresponding to the Cap Ghir and Imssouane, the second gathering sites 1 and 4 corresponding to Anza and Essaouirra sites. The statistical analysis revealed that there was a negative correlation between the presence of $V$. parahaemolyticus and salinity. In Alabama Gulf of Mexico, Johnson et al. (2010) reported that there was no relation between salinity and Vibrio densities. In contrast, in Mississippi, a significant positive relationship with salinity was identified (Johnson et al. 2010). This is due to the fact that the salinity is not the same at both sites. Other studies have also identified the importance of salinity to Vibrios densities (Motes et al. 1998; Lipp et al. 2001; Martinez-Urtaza et al. 2008). The salinity ranges in these studies varied, but all were narrower.

In conclusion, the results noted in the present study showed the $V$. alginolyticus was the predominant Vibrio spp. in the four sites of sampling; additionally, it was also denoted that faecal contamination was high in Anza and Essaouira with a significant prevalence of Salmonella in 
both sites. Fecal contamination may have been introduced into the coastal by wastewaters and rainfall. Finally, no relationship was established between the presence of Vibrio spp., Salmonella spp. and fecal pollution, which represents additional evidence indicating that the presence of Vibrio in the area is a natural event.

\section{Competing interests}

The authors declare that they have no competing interests.

\section{Authors' contributions}

$\mathrm{MH}$ carried out the experiment of this article and participated in the written of this manuscript. MR participated in the written, the interpretation of the results, the correction of manuscript, and the coordination between all authors. $\mathrm{CN}$ a part of the bacteriological identification are done under direction of $\mathrm{CN}$. $\mathrm{HF}$ participated in the written, the interpretation of the results and the correction of manuscript. MUJ participated in the interpretation of results. All authors are read and approved the final manuscript

\section{Acknowledgements}

This work is conducted to contribute partially in the aims of agricultural research program for the development between France and Morocco (PRAD) project N09-07 (2010).

\section{Author details}

${ }^{1}$ Faculty of Sciences, Laboratory of Biotechnology \& Valorisation of Natural Resources, University Ibn Zohr, Agadir, Morocco. 'Laboratory of Microbiology, National Health Security Food Office (ONSSA), Agadir, Morocco. ${ }^{3}$ Reader in Infection and Immunology Department of Biology and Biochemistry, University of Bath, BA2 7AY Bath, United Kingdom.

Received: 17 March 2014 Accepted: 14 May 2014

Published: 24 May 2014

\section{References}

Bakr WMK, Hazzah WA, Abaza AF (2011) Detection of Salmonella and Vibrio species in some seafood in Alexandria. J American Sci 7(9):663-668

Blanco-Abad V, Ansede-Bermejo J, Rodriguez-Castro A, Martinez-Urtaza J (2009) Evaluation of different procedures for the optimized detection of Vibrio parahaemolyticus in mussels and environmental samples. Int J Food Microbiol 129:229-236

Bouchriti N, Hamouda A, Karib H, Oumokhtar B, Yaakoubi I (2001) Appréciation de la qualité bactériologique des huitres Crassostrea gigas commercialisées à Rabat. Animalis 2:26-35

Boutaib R, Marhraoui M, Oulad Abdellah MK, Bouchrif B (2011) Comparative study on faecal contamination and occurrence of Salmonella spp. and Vibrio parahaemolyticus in two species of shellfish in Morocco. Open Environ Sci 5:30-37

Brands DA, Inman AE, Gerba CP, Maré J, Billington SJ, Saif LA, Levine JF, Joens LA (2005) Prevalence of Salmonella spp. in oysters in the United States. Appl Environ Microbiol 7:893-897

Cavallo RA, Stabili L (2002) Presence of vibrios in seawater and Mytilus galloprovincialis (Lam) from the Mar Piccolo of Taranto (Ionian Sea). Water Res 36:3719-3726

Chakraborty S, Nair GB, Shinoda S (1997) Pathogenic vibrios in the natural aquatic environment. Rev Environ Health 12:63-80

Cohen N, Karib H (2007) Vibrio spp. dans les produits de la pêche: Risques et prévention. In: Revue les technologies de laboratoire. pp 4: 4-10

Cossa D (1989) A review of the use of Mytilus spp. as quantitative indicators of cadmium and mercury contamination in coastal waters. Oceanol Acta 12:417-432

Covazzi Harriague A, Brino MD, Zampini M, Albertelli G, Pruzzo C, Misic C (2008) Vibrios in association with sedimentary crustaceans in three beaches of the northern Adriatic Sea (Italy). Mar Pollut Bull 56:574-579

Croci L, Suffredini E, Cozzi L, Toti L, Ottavini D, Pruzzo C, Serratore P, Fischetti R, Goffredo E, Loffredo G, Mioni R (2007) Comparison of different biochemical and molecular methods for the identification of Vibrio parahaemolyticus. J Appl Microbiol 102:229-237

Desenclos JC, Bouvet P, Pierre V, Brisabois A, Fremy S, Lahellec C, Grimont F, Grimont PAD (1996) Épidémiologie des infections à Salmonella: tendances récentes en France et en Europe. Bulletin de la société Francaises de microbiologie 11:209-215
Di Pinto A, Terio V, Novello L, Tantillo G (2011) Comparison between thiosulphate-citratebile salt sucrose (TCBS) agar and CHROMagar Vibrio for isolating Vibrio parahaemolyticus. Food Control 22(1):124-127

FDA (2004) Bacteriological Analytical Manual. Chapter 9, Vibrio. In: Food and Drug Administration, Center for Food Safety and Applied Nutrition. Office of Seafood, Washington, DC

Goldberg ED, Bown VT, Farringtion JW, Harvey G, Marin JH, Parker PL, Risebrough RW, Robertson W, Schneider E, Gamble E (1978) The Mussel Watch. Environ Conserv 5:101-125

Hara-Kudo Y, Nishina T, Nakagawa H, Konuma H, Hasegawa J, Kumagai S (2001) Improved Method for Detection of Vibrio parahaemolyticus in Seafood. Appl Environ Microbiol 67:5819-5823

Hervio-Heath D, Colwell RR, Derrien A, Robert-Pillot A, Fournier JM, Pommepuy M (2002) Occurrence of pathogenic vibrios in coastal areas of France. J Appl Microbiol 92:1123-1135

Huss HH (1997) Control of indigenous pathogenic bacteria in seafood. Food Control 8(2):91-98

International Organization for Standardization ISO/TS 16649-3 (2005) Horizontal method for the enumeration of Bglucuronidase-positive Escherichia coli - Part 3: Most probable number technique using 5-bromo-4-chloro-3-indolyl B- Dglucuronide. In: Annual Report 2005. International Organization for Standardization, (Classification index V08-031-3) 16649-3

International Standards Organization. ISO 6579 (2002) Horizontal method for the detection of Salmonella spp. (including S. Typhi and S. Paratyphi). In: Annual report 2002. International Organization for Standardization, (Classification index V08-013) 6579

Johnson CN, Flowers AR, Noriea NF, Zimmerman AM, Bowers JC, DePaola A, Grimes DJ (2010) Relationships between Environmental Factors and Pathogenic Vibrios in the Northern Gulf of Mexico. J Appl Microbiol 76:7076-7084

Kleinheinz GT, McDermott CM, Hughes S, Brown A (2009) Effects of rainfall on E. coli concentrations at Door County, Wisconsin beaches. Int J of Microbiol 9: article ID 876050 accessed at http://dx.doi.org/10.1155/2009/876050

Lhafi SK, Kuhne M (2007) Occurrence of Vibrio spp. in blue mussels (Mytilus edulis) from the German Wadden Sea. Int J Food Microbiol 116:297-300

Lipp EK, Rodriguez-Palacios C, Rose JB (2001) Occurrence and distribution of the human pathogen Vibrio vulnificus in a subtropical Gulf of Mexico estuary. Hydrobiologia 460:165-173

Martinez-Urtaza J, Lozano-Leon A, Varela-Pet J, Trinanes J, Pazos Y, Garcia-Martin O (2008) Environmental determinants of the occurrence and distribution of Vibrio parahaemolyticus in the rias of Galicia, Spain. Appl Environ Microbiol 74:265-274

Matté GR, Matté MH, Sato MIZ, Sanchez PS, Rivera IG, Martins MT (1994) Potentially pathogenic vibrios associated with mussels from a tropical region on the Atlantic coast of Brazil. J Appl Bac 77(3):281-287

Mimouni R (2004) Etude microbiologique des eaux usées dans le Grand Agadir: Épuration par infiltration-percolation, impact sur l'environnement marin et réutilisation en agriculture. In: Thése de Doctorat d'Etat. Université Ibnou Zohr. Faculté des Sciences, Agadir. Maroc, p 170

Mimouni R, Ait Alla A, EL Anajjar M, EL Hachimi MY, Finance C, Moukrim A (2002) Impact du rejet des eaux usées sur la qualité microbiologique des plages de la baie d'Agadir (Maroc). J Eur Hydrol 33(1):115-123

Mimouni R, El Anajjar M, Finance C, Moukrim A (2003) Distribution des coliformes fécaux dans la baie d'Agadir (Sud-ouest du Maroc). Cahiers de l'Association Scientifique Européenne pour l'Eau et la Sante 8(1):57-60

Motes ML, DePaola A, Cook DW, Veazey JE, Hunsucker JC, Garthright WE, Blodgett RJ, Chirtel SJ (1998) Influence of water temperature and salinity on Vibrio vulnificus in Northern Gulf and Atlantic Coast oysters (Crassostrea virginica). Appl Environ Microbiol 64:1459-1465

Normanno G, Parisi A, Addante N, Quaglia NC, Dambrosio A, Montagna C, Chiocco D (2006) Vibrio parahaemolyticus, Vibrio vulnificus and microorganisms of fecal origin in mussels (Mytilus galloprovincialis) sold in the Puglia region (Italy). J Food Microbiol 106(2):219-222

Oliver JD, Kaper JB (1997) Vibrios. In: Doyle MP (ed) Food Microbilology: Fundamentals and Frontiers. ASM Press, Washington D.C, pp 228-264

Orbi A (1991) Fluctuation des vents et variabilité de l'upwelling le long de la côte Atlantique marocaine. Symposium International sur la pollution des eaux marines (SIPEM), Casablanca, Morocco, pp 20-22

Potasman I, Paz A, Odeh M (2002) Infectious outbreaks associated with bivalve shellfish consumption: a worldwide perspective. Clin Infect Dis 35:921-928 
Ramade F (1992) Précis d'Écotoxicologie. Masson p, Paris, 300

Ripabelli G, Sammarco ML, Grasso GM, Fanelli I, Caprioli A, Luzzi I (1999)

Occurrence of Vibrio and other pathogenic bacteria in Mytilus

galloprovincialis (mussels) harvested from Adriatic Sea, Italy. J Food Microbiol 49(1-2):43-48

Setti I, Rodriquez-Castro A, Pata MP, Cadarso-Suarez C, Yacoubi B, Bensmael L, Moukrim A, Martinez-Urtaza J (2009) Characteristics and dynamics of Salmonella contamination along the coast of Agadir, Morocco. Appl Environ Microbiol 75(24):7700-7709

Simental L, Martinez-Urtaza J (2008) Climate patterns governing the presence and permanence of Salmonellae in coastal areas of Bahia de Todos Santos, Mexico. Appl Environ Microbiol 74(19):5918-5924

Yamazaki K, Esiobu N (2012) Environmental Predictors of Pathogenic Vibrios in South Florida Coastal Waters. Open Epidemiol J 5:1-4

ZoBell CE (1941) Studies on Marine Bacteria in the cultural requirements of heterotrophic aerobes. J Mar Res 4:42-75

doi:10.1186/2193-1801-3-265

Cite this article as: Mannas et al:: Occurrence of Vibrio and Salmonella species in mussels (Mytilus galloprovincialis) collected along the Moroccan Atlantic coast. SpringerPlus 2014 3:265.

\section{Submit your manuscript to a SpringerOpen ${ }^{\circ}$ journal and benefit from:}

- Convenient online submission

- Rigorous peer review

- Immediate publication on acceptance

- Open access: articles freely available online

- High visibility within the field

- Retaining the copyright to your article

Submit your next manuscript at $\gg$ springeropen.com 